\title{
Erratum to: 'Early versus late initiation of renal replacement therapy in critically ill patients with acute kidney injury (The ELAIN-Trial): study protocol for a randomized controlled trial'
}

Alexander Zarbock ${ }^{1 *}$, Joachim Gerß ${ }^{2 \dagger}$, Hugo Van Aken ${ }^{1}$, Andreea Boanta', John A. Kellum ${ }^{3}$ and Melanie Meersch ${ }^{1}$

Unfortunately, the original version of this article [1] contained an error. There is a typo in one of the formulas in the PDF version of this article on page six, though the HTML version has the correct formula. To avoid confusion the correct formula has been included here.

$$
C(p 1, p 2):=1-\phi\left[\sqrt{\frac{1}{2}} \cdot \phi^{-1}(1-p 1)+\sqrt{\frac{1}{2}} \cdot \phi^{-1}(1-p 2)\right] \leq \alpha_{c}
$$

\section{Author details}

'Department of Anesthesiology, Intensive Care and Pain Medicine, University of Münster, 48149 Münster, Germany. ${ }^{2}$ Institute of Biostatistics and Clinical Research, University of Münster, 48149 Münster, Germany. ${ }^{3}$ Department of Critical Care Medicine, Clinical Research, Investigation, and System Modelling of Acute Illness (CRISMA) Center, University of Pittsburgh, Pittsburgh 48149, United States.

Received: 10 May 2016 Accepted: 10 May 2016

Published online: 23 May 2016

\section{Reference}

1. Zarbock A, Gerß J, Van Aken H, Boanta A, Kellum JA, Meersch M. Early versus late initiation of renal replacement therapy in critically ill patients with acute kidney injury (The ELAIN-Trial): study protocol for a randomized controlled trial. Trials. 2016;17:148.

\footnotetext{
* Correspondence: zarbock@uni-muenster.de

${ }^{\dagger}$ Equal contributors

'Department of Anesthesiology, Intensive Care and Pain Medicine, University of Münster, 48149 Münster, Germany

Full list of author information is available at the end of the article
}

Submit your next manuscript to BioMed Central and we will help you at every step:

- We accept pre-submission inquiries

- Our selector tool helps you to find the most relevant journal

- We provide round the clock customer support

- Convenient online submission

- Thorough peer review

- Inclusion in PubMed and all major indexing services

- Maximum visibility for your research

Submit your manuscript at www.biomedcentral.com/submit 